\title{
Effects of daily changes in environmental factors on the abundance and richness of Odonata
}

\author{
Efeitos das mudanças diárias dos fatores ambientais \\ sobre a abundância e a riqueza de Odonata
}

João Ânderson Fulan ${ }^{1}$, Raoul Henry² and Rosemary Cristina Souza Davanso

${ }^{1}$ Universidade Federal do Amazonas - UFAM, Rua 29 de agosto, 786, Centro, CEP 69800-000, Humaitá, AM, Brazil e-mail: joaofulan@ig.com.br

\author{
${ }^{2}$ Departamento de Zoologia, Instituto de Biociências, Universidade Estadual Paulista - UNESP, \\ Rubião Jr, s/n, CP 510, CEP 18618-000, Botucatu, SP, Brazil \\ e-mail: rhenry@ibb.unesp.br; rose@davanso.com
}

\begin{abstract}
Aim: The aim of this work was to investigate the effects of daily changes in surface water abiotic factors on the abundance of Odonata larvae and the genus richness in a lateral lake isolated from a tropical river during the nycthemeral cycle in dry and wet seasons; Methods: Macrophytes were sampled on a single day at 6-hours intervals for 24 hours (at 12:00 AM, 6:00 AM, 12:00 PM and 6:00 PM) in dry and wet periods. At each site, abiotic factors were measured as follows: air temperature, surface water temperature, dissolved oxygen, $\mathrm{pH}$, and electric conductivity. Canonical correspondence analysis (CCA) of abiotic and biological data and sampling periods was made using CANOCO program; Results: A total of 249 and 265 Odonata larvae from six genera (Acanthagrion, Cyanallagma, Telebasis, Erythemis, Erythrodiplax and Tauriphila) were sampled in association with macrophytes in wet and dry seasons, respectively. Telebasis presented the highest frequency of occurrence and was collected in all nycthemeral cycle sampling periods in both seasons. The highest abundance of dragonflies was recorded at 6:00 AM and 12:00 AM in wet and dry seasons, respectively. Anoxia was detected in wet season during the entire nycthemeral cycle, while in the dry season, the highest variability in oxygen content was observed during sunlight. Canonical correspondence analysis showed that the abundances of Telebasis and Erythemis were positively related to water electrical conductivity, temperature, and depth, while for Acanthagrion and Tauriphila, abundance showed a positive relationship to water oxygen and $\mathrm{pH}$. The variability of the abundance of Odonata due to surface water temperature, dissolved oxygen, electrical conductivity, $\mathrm{pH}$, and depth during the daily cycle was therefore evidenced; Conclusions: We suggested that the better sampling period Odonata larvae must to be carried in the morning, since that we recorded the highest densities of both wet and dry stations at that hour. We point out that our data must to be examined with caution because the low sampling effort and the reduced taxonomic resolution.
\end{abstract}

Keywords: tropical lake, nycthemeral variation, Odonata, temperature, dissolved oxygen.

Resumo: Objetivo: O objetivo deste trabalho foi investigar os efeitos da variação diária de oxigênio e da temperatura de superfície da água e outros fatores abióticos sobre a abundância e a riqueza de larvas de Odonata em uma lagoa isolada de um rio tropical durante o ciclo nictemeral nas estaçôes seca e chuvosa; Métodos: As macrófitas foram amostradas em um único dia por 24 horas em intervalos de 6 horas (00:00, 6:00, 12:00 e 18:00) nos períodos seco e chuvoso. Em cada sitio de amostragem foram medidos a temperatura do ar, temperatura de superfície da água, oxigênio dissolvido, $\mathrm{pH}$ e condutividade. Uma análise de correspondência canônica (ACC) foi realizada no programa Canoco com os dados abióticos, biológicos e períodos de amostragem; Resultados: Um total de 249 e 265 larvas de Odonata de seis gêneros (Acanthagrion, Cyanallagma, Telebasis, Erythemis, Erythrodiplax and Tauriphila) foram amostradas junto à macrófita nas estaçôes seca e chuvosa, respectivamente. Telebasis apresentou a maior freqüência de ocorrência e foi amostrado em todo ciclo nictemeral em ambas estaçôes. A maior abundância de Odonata foi registrada às 6:00 e 12:00 nas estaçóes chuvosa e seca, respectivamente. Um período anóxico foi detectado durante toda a estação chuvosa, enquanto que no 
período seco a maior variabilidade de oxigênio foi observada durante o dia. A Análise de Correspondência Canônica mostrou que as abundâncias de Telebasis e Erythemis foram positivamente correlacionadas com a condutividade elétrica, temperatura e profundidade, enquanto que Acanthagrion e Tauriphila mostraram correlaçáo positiva com o oxigênio e com o pH. Portanto, foi observada uma variância na abundância de Odonata com temperatura, oxigênio, condutividade, $\mathrm{pH}$ e profundidade durante o período de 24 horas; Conclusóes: Nós sugerimos que o melhor período de amostragem de larvas de Odonata deve ser pela manhâ, pois neste período registramos as maiores densidades nas estaçôes seca e chuvosa. Destacamos que os resultados deste trabalho devem ser interpretados com cautela devido ao baixo esforço amostral e reduzida resolução taxonômica.

Palavras-chave: lagoa tropical, variação nictemeral, Odonata, temperatura, oxigênio.

\section{Introduction}

Nycthemeral studies in tropical lakes are extremely important due to the high variability of chemical and physical characteristics of water, such as dissolved oxygen and temperature (Esteves et al., 1988). Both water dissolved oxygen concentration and temperature directly affect the abundance of Odonata larvae. The amount of dissolved oxygen in water affects the behavior, metabolism, and survival of Odonata larvae (Corbet, 1999; Hofmann and Mason, 2005). Variations in oxygen availability in lacustrine (low oxygenation) and lotic (high oxygenation) environments determine the diversity of Odonata species (Voshell and Simmons, 1978; Corbet, 1999; Fulan et al., 2008). Water temperature also has an effect on the abundance and development of Odonata larvae (Lutz, 1974; Ward, 1992; Corbet, 1999). Sites with high temperatures, such as thermal springs, tend to present low abundance and diversity of Odonata species (Corbet, 1999). However, when considering aquatic insects, Odonata are characterized by a high tolerance to changes of surface water temperature (Kondratieff and Pyott, 1987; Cobert, 1999). The importance of abiotic factors like water dissolved oxygen and temperature for the presence of Odonata larvae near macrophytes was also shown for a lake lateral to Paranapanema River, Brazil (Fulan and Henry, 2006). According to the authors, Enallagma, Homeura and Telebasis were highly sensitive to variations in dissolved water oxygen concentration and temperature during the year. Besides environmental variables, biotic factors such as predation risk can also affect macroinvertebrate distribution during the 24-hours period. Flecker (1992) recorded that Ephemeroptera larvae presented nocturnal habits to avoid predators such as fish, which are usually more active during the day. Odonata larvae are top predators and can feed on a great diversity of macroinvertebrates (Corbet, 1999). Nevertheless, Odonata larvae are also preyed on by fish and can present different behaviors. Despite the significant effect of predation on Odonata larvae, the current investigation has been limited to the effects of seasonal and nycthemeral variations in the abiotic factors on aquatic insects.

According to Corbet (1999), environmental variables and biotic factors, as predation, had an important effect on Odonata larvae density. As indicated before, a daily modification on environmental factors can occurred in distinct stations of the year. Thus, it should be expected that Odonata larvae presented a response to environmental variables as it was mentionned in literature. So, our paper intends to respond to the following question: Can environmental factors, as oxygen and temperature, explain nictemeral variation in Odonata larvae abundance in a tropical lake?

\section{Material and Methods}

\subsection{The study area}

Cavalos Lake, $23^{\circ} 29^{\prime} \mathrm{S}$ and $48^{\circ} 37^{\prime} \mathrm{W}$, is located at the mouth zone of the Paranapanema River. It flows into the Jurumirim Reservoir, located in São Paulo State, Brazil (Figure 1). It is lateral and superficially isolated from the Paranapanema River, but it may be affected by the river by underground water exchange. In a 16-month study, Carmo (2007) showed that underground water flowed in the river-lake direction during $64 \%$ of the time and otherwise in the remaining period.

\subsection{Macrophyte and Odonata larva sampling}

Three great stands were selected in dry and wet seasons, according to the arrangement shown in Figure 1 (P1, P2, and P3). In each stand, only one macrophyte sampling was carried out; thus totaling three samples each for the wet and dry seasons. Macrophytes were sampled on a single day 


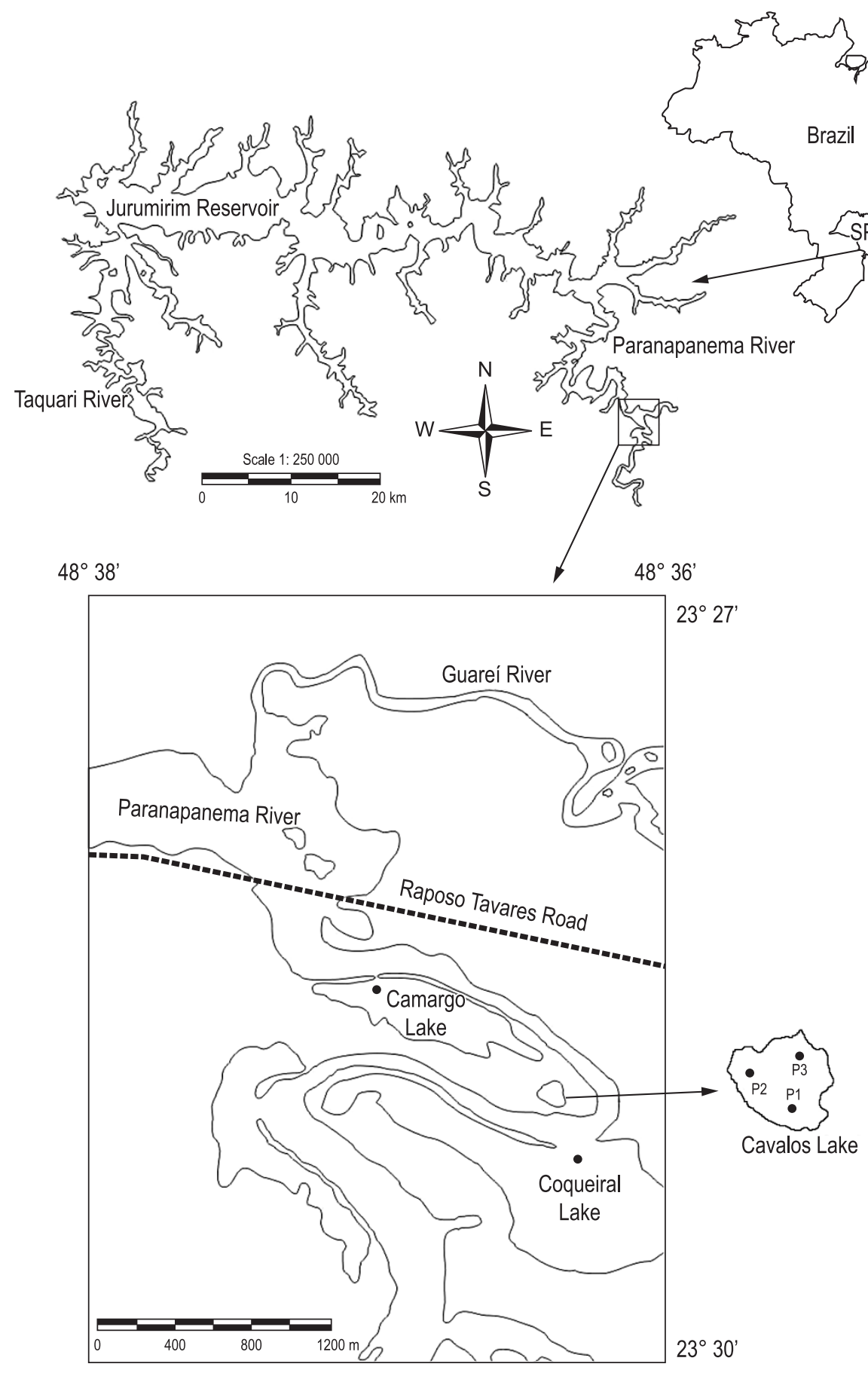

Figure 1. Study area - the mouth zone of the Paranapanema River into Jurumirim Reservoir (São Paulo, Brazil) and Cavalos Lake (Odonata larvae and surface water were sampled at sites P1, P2, and P3).

at 6-hours intervals for 24 hours (at 12:00 AM, 6:00 AM, 12:00 PM and 6:00 PM) in dry and wet periods. The 6-hours interval corresponds to the minimum time necessary to wash the plants and carry out physical and chemical analyses in laboratory. Aquatic plants were sampled with a $0.25-\mathrm{mm}$ mesh net mounted on a $0.07-\mathrm{m}^{2}$ square metal frame. The sampling equipment was carefully inserted below $S$. auriculata in the selected sites and the plants with Odonata larvae were transferred to plastic bags. In the laboratory, Odonata larvae were carefully removed by moving the plants in circular movements in three buckets containing 8 and $4 \%$ formaldehyde, and water, respectively (Fulan and Henry, 2006). The content of each bucket was filtered with a $0.25-\mathrm{mm}$ mesh net sieve. Odonata 
larvae retained on the sieve were preserved in $70 \%$ alcohol and identified using an identification key (Costa et al., 2004).

\subsection{Abiotic factors}

At each site, abiotic factors were measured as follows: air temperature by alcohol thermometer, surface water temperature by Toho Dentam thermistor, dissolved oxygen by Golterman et al. (1978), pH by Micronal B-380 pHmeter, and electric conductivity corrected to $25{ }^{\circ} \mathrm{C}$ by Golterman et al. (1978).

\subsection{Data analysis}

Canonical correspondence analysis (CCA) of abiotic and biological data and sampling periods was made using CANOCO program (Ter Braak and Smilauer, 2002). The significance level of the first two canonical axes was tested with the Monte Carlo test (499 permutations, $\mathrm{p}<0.05$ ) and the probability of hazard distribution of data was determined. CCA data were $\log (y+1)$ transformed for performing CANOCO.

\section{Results}

Odonata larvae from six genera (Acanthagrion, Cyanallagma, Telebasis, Erythemis, Erythrodiplax and
Tauriphila) were sampled in wet (249 larvae) and dry (265 larvae) seasons. The highest abundances were observed at 6:00 AM in wet season and at 12:00 AM in dry season. Telebasis presented the highest frequency of occurrence, being observed in all sampling periods during the nycthemeral cycle and in both wet and dry seasons (Table 1). In Table 2, we can observe that the surface water dissolved oxygen concentration was zero in all periods (except at 6:00 PM) of the wet season, while in the dry season, the highest dissolved oxygen concentration $\left(3.74 \mathrm{mg} . \mathrm{L}^{-1}\right)$ was found at 12:00 PM. The values of surface water temperature, electric conductivity, and depth were higher in wet season.

The CCA Monte Carlo test revealed that the first axis $(\mathrm{F}=4.829, \mathrm{p}<0.02)$ and all the canonical axes together $(\mathrm{F}=4.132, \mathrm{p}<0.02)$ were significant and represented relationships between abiotic and biological variables. The first and second axes explained together $70.3 \%$ of the data variability (auto-values 0.579 and 0.124 for axes 1 and 2, respectively).

Telebasis, Erythemis and Acanthagrion presented significant correlations with axis 1, while Tauriphila did with axes 1 and 2 (Table 3). Water dissolved oxygen, temperature, electrical conductivity,

Table 1. Abundance and richness of Odonata genera sampled within macrophyte Salvinia auriculata in Cavalos Lake at different hours of nycthemeral cycle during rainy and dry seasons.

\begin{tabular}{|c|c|c|c|c|c|c|c|c|}
\hline \multirow[t]{2}{*}{ Genera } & \multicolumn{4}{|c|}{ Rainy season } & \multicolumn{4}{|c|}{ Dry season } \\
\hline & 12:00 AM & 6:00 AM & 12:00 PM & 6:00 PM & 12:00 AM & 6:00 AM & 12:00 PM & 6:00 PM \\
\hline Acanthagrion (Aca), (Selys, 1876) & 5 & 0 & 0 & 0 & 90 & 90 & 0 & 0 \\
\hline Cyanallagma (Aca), (Kennedy, 1920) & 0 & 90 & 0 & 0 & 967 & 290 & 171 & 114 \\
\hline Telebasis (Tel), (Selys, 1875) & 162 & 319 & 200 & 186 & 214 & 38 & 52 & 14 \\
\hline Erythemis (Ery), (Hagen, 1861) & 43 & 43 & 62 & 43 & 19 & 0 & 14 & 0 \\
\hline Erythrodiplax (Erd), (Brauer, 1968) & 0 & 0 & 14 & 5 & 14 & 0 & 0 & 10 \\
\hline Tauriphila (Tau), (Kirby, 1889) & 0 & 5 & 0 & 10 & 124 & 419 & 238 & 138 \\
\hline Genus richness & 3 & 4 & 3 & 4 & 6 & 4 & 4 & 4 \\
\hline TOTAL & 210 & 457 & 276 & 244 & 1428 & 837 & 475 & 276 \\
\hline
\end{tabular}

Table 2. Abiotic factors measured on Salvinia auriculata stands in Cavalos Lake in different hours of the nycthemeral cycle during rainy and dry seasons (DO - dissolved oxygen; K25 - electrical conductivity corrected to $25{ }^{\circ} \mathrm{C}$; $\mathrm{T}$ - surface water temperature).

\begin{tabular}{|c|c|c|c|c|c|c|c|c|}
\hline \multirow{2}{*}{$\begin{array}{c}\text { Variables/ } \\
\text { Hour }\end{array}$} & \multicolumn{4}{|c|}{ Rainy season } & \multicolumn{4}{|c|}{ Dry season } \\
\hline & $12: 00 \mathrm{AM}$ & 6:00 AM & 12:00 PM & 6:00 PM & 12:00 AM & 6:00 AM & 12:00 PM & 6:00 PM \\
\hline $\mathrm{DO}\left(\mathrm{mg} \cdot \mathrm{L}^{-1}\right)$ & 0.00 & 0.00 & 0.00 & 0.22 & 3.20 & 1.74 & 3.74 & 3.57 \\
\hline $\mathrm{pH}$ & 5.48 & 5.68 & 5.98 & 5.95 & 6.37 & 6.40 & 6.42 & 6.50 \\
\hline $\mathrm{K}_{25}\left(\mu \mathrm{S} . \mathrm{cm}^{-1}\right)$ & 104.13 & 109.80 & 102.00 & 102.47 & 47.60 & 54.77 & 68.40 & 46.70 \\
\hline $\mathrm{T}\left({ }^{\circ} \mathrm{C}\right)$ & 22.97 & 22.10 & 23.27 & 23.10 & 16.67 & 16.00 & 21.17 & 19.13 \\
\hline Depth (m) & 1.77 & 1.60 & 1.70 & 1.77 & 1.57 & 1.57 & 1.28 & 1.24 \\
\hline
\end{tabular}


and depth presented a correlation with axis 1 in sampling periods 6:00 AM, 12:00 PM and 6:00 PM as well (Tables 4 and 5).

The abundances of Telebasis and Erythemis were positively affected by water electrical conductivity, temperature, and depth, while the abundances of Acanthagrion and Tauriphila showed a positive correlation with water dissolved oxygen and $\mathrm{pH}$ (Figure 2).

\section{Discussion}

Daily changes on environmental variables affect the distribution of aquatic insects. In this paper, more evidences were added showing the effects of environmental variables during the diurnal cycle on Odonata larvae.

In aquatic ecosystems, oxygen availability is one of the limiting factors of the survival of insect larvae, such as Odonata (Gaufin et al., 1974; Corbet, 1999; Hoback and Stanley, 2001; Apodaca and Chapman, 2004). In the dry season, CCA showed

Table 3. Correlations between abundance of Odonata and the first two CCA axes.

\begin{tabular}{lccc}
\hline \multicolumn{1}{c}{ Genera } & Abbreviation & Axis 1 & Axis 2 \\
\hline Acanthagrion & Aca & $-0.568^{*}$ & -0.301 \\
Cyanallagma & Cya & -0.480 & 0.335 \\
Erythemis & Ery & $0.998^{*}$ & -0.098 \\
Erythrodiplax & Erd & 0.428 & -0.220 \\
Tauriphila & Tau & $-0.656^{*}$ & $-0.581^{*}$ \\
Telebasis & Tel & $0.998^{*}$ & -0.023 \\
\hline
\end{tabular}

$* \mathrm{P}<0.05$ that the oxygen concentration affected Telebasis and Erythemis negatively and Acanthagrion and Tauriphila positively during the nycthemeral cycle. An annual study of Odonata larvae conducted in a lake lateral to the Paranapanema River showed a different result as compared with those of the present investigation. Acanthagrion, Erythemis and Tauriphila did not exhibit any correlation with

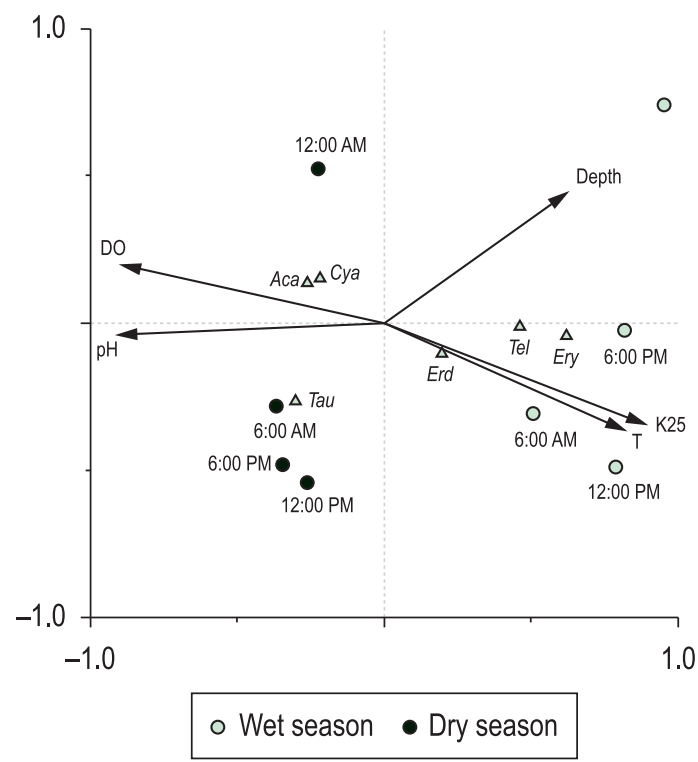

Figure 2. CCA ordination (axes 1 and 2) among abundance of Odonata larvae, abiotic variables, and sampling hours (6:00 AM, 12:00 PM, 6:00 PM, and 12:00 AM) during rainy and dry seasons. (Abbreviations, see Tables 2 and 3).

Table 4. Canonical coefficients and intra-set correlations of abiotic variables with the first two CCA axes.

\begin{tabular}{|c|c|c|c|c|c|}
\hline \multirow{2}{*}{$\begin{array}{c}\text { Environmental } \\
\text { variables }\end{array}$} & \multirow[t]{2}{*}{ Abbreviation } & \multicolumn{2}{|c|}{ Canonical coefficients } & \multicolumn{2}{|c|}{ Intra-set correlation } \\
\hline & & Axis 1 & Axis 2 & Axis 1 & Axis 2 \\
\hline Dissolved oxygen & DO & $-0.897^{*}$ & 0.199 & $-0.893^{*}$ & 0.166 \\
\hline Conductivity & $\mathrm{K}_{25}$ & $0.896^{*}$ & -0.348 & $0.892^{*}$ & -0.291 \\
\hline Surface water temperature & $\mathrm{T}$ & $0.823^{*}$ & -0.371 & $0.819^{*}$ & -0.311 \\
\hline Depth & Depth & $0.629^{*}$ & 0.445 & $0.625^{*}$ & 0.372 \\
\hline $\mathrm{pH}$ & $\mathrm{pH}$ & $-0.915^{*}$ & -0.041 & $-0.911^{*}$ & -0.034 \\
\hline
\end{tabular}

$* \mathrm{P}<0.05$

Table 5. Correlations between abundance of Odonata and sampling hours during the rainy and dry seasons and the first two CCA axes.

\begin{tabular}{|c|c|c|c|c|c|}
\hline \multirow[t]{2}{*}{ Hour } & \multirow[t]{2}{*}{ Abbreviation } & \multicolumn{2}{|c|}{ Rainy season } & \multicolumn{2}{|c|}{ Dry season } \\
\hline & & Axis 1 & Axis 2 & Axis 1 & Axis 2 \\
\hline $12: 00 \mathrm{AM}$ & $12: 00 \mathrm{AM}$ & -0.426 & 0.414 & 0.407 & -0.252 \\
\hline 6:00 AM & 6:00 AM & *-0.882 & -0.318 & *0.576 & 0.272 \\
\hline 12:00 PM & 12:00 PM & $*-0.609$ & -0.411 & 0.244 & -0.407 \\
\hline 6:00 PM & 6:00 PM & *-0.795 & -0.024 & 0.443 & -0.414 \\
\hline
\end{tabular}

${ }^{*} \mathrm{P}<0.05$ 
dissolved oxygen concentration, and Telebasis was positively influenced by dissolved oxygen (Fulan and Henry, 2006). Apparently, Acanthagrion, Erythemis, Tauriphila, and Telebasis are thus more susceptible to changes of oxygen availability during the daily cycle rather than during the annual cycle. Although the changes of oxygen availability affected four of the six Odonata genera observed in this study, Cyanallagma and Erythrodiplax were tolerant enough of environmental variations, including of oxygen availability. Morphological, physiological, and behavioral adaptations in low water oxygenation conditions had already been observed for macro-invertebrates (Hoback and Stanley, 2001; Apodaca and Chapman, 2004).

Besides oxygen, the surface water temperature also influenced the distribution of Odonata larvae. Only four orders of aquatic insects (Odonata, Hemiptera, Diptera, and Coleoptera) are resistant to significant changes in water temperature (Corbet, 1999). Odonata larvae tolerate changes in water temperature through an enzymatic mechanism that promotes a fast physiological response (Schott and Brusven, 1980). In the present study, only Cyanallagma and Erythrodiplax tolerated variations in surface water temperature. Temperature changes positively affected Telebasis and Erythemis and negatively affected Acanthagrion and Tauriphila. Some Anisoptera and Zygoptera families are sensitive to variations in water temperature, as was reported for Acanthagrion, Erythemis, Telebasis and Tauriphila. (Corbet, 1999; Fulan and Henry, 2006).

In addition to the water dissolved oxygen concentration and surface temperature, other environmental factors, such as electrical conductivity, $\mathrm{pH}$, and depth also had an effect on the abundance of Odonata larvae. CCA showed positive effects of electrical conductivity and depth on the abundance of Telebasis and Erythemis and of $\mathrm{pH}$ on the abundances of Acanthagrion and Tauriphila. Erythemis also showed a positive relationship with electrical conductivity in a lake lateral to the Paranapanema River, Brazil (Fulan and Henry, 2006). Differently from what was observed in the present work, Telebasis and Erythemis exhibited a negative correlation with depth (Corbet, 1999). High pressure in sites with high depth directly affects the larvae tracheal system, reducing gas exchange (Corbet, 1999). Although depth can affect Odonata larvae negatively during the daily cycle, we recorded a positive effect on Telebasis and Erythemis. Water $\mathrm{pH}$, as well as depth, showed a positive effect on the abundances of Acanthagrion and Tauriphila. Zygoptera larvae, such as Acanthagrion., are actually highly tolerant to $\mathrm{pH}$ variation when compared with Anisoptera, such as Tauriphila (Corbet, 1999). However, both Acanthagrion and Tauriphila are little tolerant to water $\mathrm{pH}$ variation during the nycthemeral cycle.

None of the measured environmental variables completely explains the Odonata distribution in the 24-hours period. Predation risk of Odonata larvae by fish must also be considered, since it directly affects the larval behavior. Carvalho et al. (2005) studied the monthly variation of fish composition and distribution in Cavalos Lake from July, 1998 to June, 1999. According to the authors, 5481 individuals of four orders, Characiformes, Siluriformes, Gymnoformes, and Perciformes, were captured in the lake. Despite Cavalos Lake being a small and isolated lake, a significant density of fish that inhabit this environment may prey on Odonata larvae. Flecker (1992) observed in an experiment that Ephemeroptera larvae are conditioned to search refuge, including in the absence of predators. Also, Bass (2004) recorded that in natural conditions, the number of invertebrates recorded during the nocturnal period was approximately four times higher than in the diurnal period, due to a lower predation risk at night. Similar to Bass' (2004) observations, we found the highest number of larvae at 12:00 AM (nocturnal period) in the dry season. This observation shows that predation can be a determinant of Odonata distribution. However, during the wet season, we recorded a very low number of larvae. In this period, the abiotic factors may have important effects on the Odonata larvae distribution. In the wet season, we recorded anoxia on the water surface in all sampling periods and also an increase of more than $100 \%$ in water conductivity as compared with the dry season.

All the six Odonata genera (Acanthagrion, Cyanallagma, Eryrhemis, Erythrodiplax, Tauriphila and Telebasis) described in this work had already been reported near macrophytes (Carvalho and Nessimian, 1998; Fulan and Henry, 2006). However, despite sharing the same habitat, Odonata were diversely affected by abiotic factors, the most important ones being water dissolved oxygen and temperature. As their affects on the abundance of aquatic insects during the daily cycle is highly relevant, the sampling period of Odonata must be reported. In future works, involving environmental monitoring of Odonata larvae, we suggested that the better sampling period must to be carried in the morning, since that we recorded the highest densities of both wet and dry stations at that hour. We point out that our data must to be examined 
with caution because the low sampling effort and the reduced taxonomic resolution.

\section{Acknowledgements}

João Ânderson Fulan is grateful to CAPES for the research grant. We would like to express our acknowledgements to Mr. Hamilton Antonio Rodrigues and Mr. Lúcio Miguel de Oliveira for field assistance, and to Mr. Laerte José da Silva for the English revision.

\section{References}

APODACA, CK. and CHAPMAN, LJ. 2004. Adult damselflies of Kibale National Park, Uganda: Habitat associations and seasonal occurrence. Odonatologica, vol. 33, p.129-146.

BASS, D. 2004. Diurnal Stream Drift of Benthic Macroinvertebrates on the Small Oceanic Island of Dominica, West Indies. Caribbean Journal of Science, vol. 40, no. 2, p. 245-252.

CARMO, CF. 2007. Influência do aqǘfero freático na dinâmica de nutrientes (nitrogênio e fósforo) em lagoas com diferentes características hidrodinâmicas. São Carlos: Universidade Federal de São Carlos. [Tese de Doutorado em Engenharia Ambiental]

CARVALHO, AL. and NESSIMIAN, JL. 1998. Odonata do Estado do Rio de Janeiro, Brasil: hábitat e hábitos das larvas. In NESSIMIAN, JL. and CARVALHO, A., eds. Ecologia de insetos aquáticos. Rio de Janeiro: PPGE-UFRJ. p. 3-28.

CARVALHO, ED., MARCUS, LR., FORESTI, F. and SILVA, VFB. 2005. Fish assemblage attributes in a small oxbow lake (Upper Paraná River Basin, São Paulo State, Brazil): species composition, diversity and ontogenetic stage. Acta Limnologica Brasiliensia, vol. 17 , no. 1 , p. 45-56.

CORBET, PS. 1999. Dragonflies: behavior and ecology. New York: Cornell University Press. 829 p.

COSTA, JM., SOUZA, LOI., LOURENÇO, AN. and OLDRINI, BB. 2004. Chave para identificação das famílias e gêneros das larvas conhecidas de Odonata do Brasil: comentários e registros bibliográficos. Publicaçóes Avulsas do Museu Nacional, vol. 99, p. 3-42.

ESTEVES, FA., BOZELLI, RL., CAMARGO, AFM., ROLAND, F. and THOMAZ, SM. 1988. Variação diária (24h) de temperatura, oxigênio dissolvido, $\mathrm{pH}$ e alcalinidade em duas lagoas costeiras do Estado do Rio de Janeiro e suas implicaçóes no metabolismo destes ecossistemas. Acta Limnologica Brasiliensia, vol. 2, p. 99-127.
FLECKER, A.S. 1992. Fish predation and the evolution of invertebrate drift periodicity: evidence from neotropical streams. Ecology, vol. 73, no. 2, p. 438-448. http://dx.doi.org/10.2307/1940751

FULAN, JA. and HENRY, R. 2006. The Odonata (Insecta) assemblage on Eichhornia azurea (Sw.) Kunth (Pontederiaceae) stands in Camargo Lake, a lateral lake on the Paranapanema River (state of São Paulo, Brazil), after an extreme inundation episode. Acta Limnologica Brasiliensia, vol. 18, no. 4, p. 423-431.

FULAN, JA., RAIMUNDO, R. and FIGUEIREDO, D. 2008. Habitat characteristics and dragonflies diversity and abundance in the Guadiana River, eastern of the Alentejo, Portugal. Boletín de la Asociación Española de Entomología, vol. 32, no. 3-4, p. 327-340.

GAUFIN, AR., CLUBB, R. and NEWELL, R. 1974. Studies on the tolerance of aquatic insect to low oxygen concentrations. Great Basin Naturalist, vol. 34, p. 45-59.

GOLTERMAN, KL., CLYMO, RS. and OHMSTAD, MAM. 1978. Methods for physical and chemical analysis offreshwaters. Oxford: Scientific Publications. $213 \mathrm{p}$.

HOBACK, WW. and STANLEY, DW. 2001. Mini review: insects in hypoxia. Journal of Insect Physiology, vol. 47, p. 533-542.

HOFMANN, TA. and MASON, CF. 2005. Habitat characteristics and the distribution of Odonata in a lowland river catchment in eastern England. Hydrobiologia, vol. 539, p. 137-147. http://dx.doi. org/10.1007/s10750-004-3916-1

KONDRATIEFF, BC. and PYOTT, CJ. 1987. The Anisoptera of the Savannah River Plant, South Carolina, United States: thirty years later. Odonatologica, vol. 16, p. 9-23.

LUTZ, PA. 1974. Effects of Temperature and Photoperiod on Larval Development in Tetragoneuria Cynosura (Odonata: Libellulidae). Ecology, vol. 55, no. 2, p. 370-377.

SCHOTT, RJ. and BRUSVEN, MA. 1980. The ecology and electrophoretic analysis of the damselfly, Argia vivida Hagen, living in a geothermal gradient. Hydrobiologia, vol. 69, p. 261-265.

TER BRAAK, CJF. and SMILAUER, P. 2002. CANOCO reference manual and CanoDraw for Windows user's guide: software for canonical community ordination. Version 4.5. New York: Microcomputer Power. 200 p.

VOSHELL, JR. and SIMMONS, GM. 1978. The Odonata of a new Reservoir in the southeastern United States. Odonatologica, vol. 7, no 1, p. 67-76.

WARD, JV. 1992. Aquatic insect ecology. New York: John Wiley and Sons. 466 p. 